\title{
Genetic Evidence of Stable Northward Extension of Pinus Thunbergii Forests in the Democratic People's Republic Korea
}

Un-Hyang Ho ( $\sim$ uh.ho@ryongnamsan.edu.kp )

Kim II Sung University

Sam-Rang Song

Kim Sung University

Hak-Song Pak

Kim II Sung University

Kang Kim

Kim II Sung University

Tong-Su Ho

Kim II Sung University

II-Yop Ju

Natural Academy

\section{Research Article}

Keywords: Japanese black pine, distribution, climate change, forest ecosystem, afforestation, gene flow

Posted Date: November 2nd, 2021

DOI: https://doi.org/10.21203/rs.3.rs-988396/v1

License: (c) (i) This work is licensed under a Creative Commons Attribution 4.0 International License. Read Full License 


\section{Abstract}

Japanese black pine with high salt tolerance may be an important constitutive element sustaining terrestrial ecosystem by playing a role of windbreak forests in coastal areas. Korean peninsula would be a notable region in clarifying distribution shift in Pinus species as it has northern distribution limit of Japanese black pine in Asia. Our main object was to verify genetic evidence of stable northward extension of P.thunbergii populations in D. P. R. Korea. We investigated genetic background of 9 populations existing in Korean peninsula using nuclear SSR markers in relation to shifts in climate factors such as temperature and precipitation. Higher genetic diversity in east group (AR=10.7 19.5) and west group ( $A R=10.3 \sim 10.7)$ compared to north group ( $A R=6.7 \sim 8.8)$ was found. When number of putative clusters $(K)=2$, whole individuals were divided into west group and north-east group, and when $\mathrm{K}=3$, north-east group can be separated into north group and east group. Phylogeographic relationship verified by means of nSSR markers suggest that substantial increment of air temperature in D. P. R. Korea allowed stable anthropogenic transfer of P.thunbergii forests and that artificial afforestation may bring rapid establishment of forest ecosystem owing to climate change.

\section{Introduction}

Increasing air $\mathrm{CO}_{2}$ emission, growing global warming resulting in climate change have an influence on global biome (Lenoir et al. 2008; Keenan et al. 2010; Etterson et al. 2010). In coastal areas, the threat of natural disaster due to climate change and global warming is increasing day by day and windbreak forests formed in these areas might play an important role in damage reduction. Forest may be integral part of the regional biome due to its fundamental position in material circulation and energy flow. Understanding genetic diversity and population dynamics of forest tree species playing an important role in forest composition and functioning in relation to climate change would assist the design of conservation strategy and forest establishment.

The negative impact of climate change on various forest tree species has been widely reported. Freire et al. (2019) assessed the effects of precipitation decrease, air temperature change resulting in frequent forest fire on afforestation of Pinus pinea L. and suggested the ways to mitigate the effect of climate change, one of that is to reduce population density. Fettig et al. (2019) reported massive extinction of Pinus ponderosa Dougl. and change of forest composition following air temperature increase accompanied by extreme drought in southern Sierra Nevada, California.

Climate change in different parts may result in change of growth and distribution of forest tree species. Misi et al. (2019) clarified that the effect of climate on tree's growth could vary between regions based on the assessment of effects of temperature and precipitation on the width of annual ring of Scots pine (Pinus sylvestris L.). Cheaib et al. (2012) assessed potential influence of air temperature, precipitation and $\mathrm{CO}_{2}$ concentration on the distribution of Scots pine in France based on several modeling methods and reported upcoming forest contraction. Nevertheless, such researches have not been widely reported in Asia.

The distribution of Japanese black pine is characterized by both natural and artificial forests (Iwaizumi et al. 2018). Because Japanese black pine forests prevent soil erosion and exhibits tolerance to salty environment, it is suitable for the establishment of wind and wave breaking forest in coastal areas (Konta, 2001; Ogawa 1979, Murai et al. 1992; Zhu et al. 2000). That's why there are many artificial forests as well as natural ones of Japanese black pine in the coastal areas (Iwaizumi et al. 2018).

To establish conservation and management strategy, we assessed genetic background of 9 Japanese black pine populations that has been formed in different period in the context of climate change. Comparing to old natural forests in western and eastern areas, most of the forests in northern part of Korean peninsula are artificial ones composed of young individuals that aimed to prevent damaging disaster. Some individuals in Thongchon are more than 25 years, even 55 60 years old. In Ongjin, there exists 90 years-old individuals and in Kosan, many individuals are more than 40 years old. Nevertheless, most individuals in the north of Kumya are 8 10 years old planted ones. Despite relatively low genetic

Page 2/12 
diversity indices of Japanese black pine populations in the north of Kumya, genetic diversity indices in all Japanese black pine populations were preserved at high level. Structure analysis showed that when $\mathrm{K}=2$, all Japanese black pine populations were divided into 2 groups-east and north+west ones, and $\mathrm{K}=3$, into 3 groups-east, west and north ones. Investigation on the climate change in northern region showed significant air temperature increase but there wasn't a big difference in precipitation during decades.

These results showed that genetic stability of Japanese black pine populations formed to reduce disastrous damage in the north of Kumya has been maintained at a quite level. It is likely for species of genus Pinus distributed in the temperate zone to expand toward north east referring to historical process from refugia to new habitat followed by present and upcoming events. Iwaizumi et al. (2018) reported association between historical expansion of Japanese black pine populations from southwest to northeast and general migration from southern refugia to north after glacial period. Korean peninsula is located in the east of Eurasia and has been reported as putative refugia of various animal and plant species (Ho et al. 2020; Kang et al. 2002). Present air temperature increase could be characterized as reappearance of this historical process. Our results support validity of northward expansion of Japanese black pine populations through recent extensive afforestation and suggest upcoming northward expansion given recent climate change.

\section{Materials And Methods}

\subsection{Sample collection, DNA extraction}

Mature needles were collected from 9 regional population individuals (Fig. 1).

The location information is as indicated in Table 1.

The age scale of sampled individuals was 3-90 years old. Sample sites represent both natural and artificial distribution of Japanese black pine. We randomly selected trees for sampling within each population keeping at least $30 \mathrm{~m}$ between sampled trees. The needles were stored at $-25^{\circ} \mathrm{C}$ before DNA extraction. Total DNA was extracted using cetyl trimethylamonium bromide (CTAB) method (Doyle and Doyle 1987; Rogers and Bendich 1988).

\subsection{SSR allele genotyping}

Genotypes of the sample trees were determined by 7 nuclear SSR markers reported previously (bcpt834: Iwaizumi et al., 2013, bcpt1075, bcpt1549, bcpt1671, bcpt1823, bcpt2532, bcpd119: Iwaizumi et al., 2018 pdms1208). PCR conditions are as follows; an initial denature at $95^{\circ} \mathrm{C}$ for $5 \mathrm{~min}, 35$ cycles of denature at $95^{\circ} \mathrm{C}$ for $1 \mathrm{~min}$, annealing at optimized temperature for $1 \mathrm{~min}$, and chain extension at $72^{\circ} \mathrm{C}$ for $1 \mathrm{~min}$, followed by a final extension for $10 \mathrm{~min}$ at $72^{\circ} \mathrm{C}$. The size of amplified fragments was determined with a DNA sequencer, ABI PRISM 3730 Genetic Analyzer (Applied Biosystems Inc.).

\subsection{Data analysis}

For each regional populations of Japanese black pine, observed heterozygosity $\left(H_{0}\right)$, expected heterozygosity $\left(H_{E}\right)$, departure from Hardy-Weinberg equilibrium were calculated using POPGENE ver. 1.32 (Yeh and Boyle 1997). FSTAT version 2.9.4 (Goudet, 2003) was used to estimate Nei's genetic diversity ( $H_{S}$ Nei, 1987), allelic richness ( $A R$; El Mousadik and Petit, 1996), inbreeding coefficient $\left(F_{I S}\right)$. To test hierarchic significance and genetic differentiation, Analysis of molecular variance and estimation of pairwise genetic differentiation were conducted using ARLEQUIN.ver.3.2.2 (Excoffier and Lischer 2010).

To assess the individual-based genetic structure including admixture, the Bayesian clustering method of Pritchard et al. (2000) was applied using STRUCTURE version 2.3.1 software (Pritchard et al. 2009). Simulations were run 15 times for each value of $\mathrm{K}(1-7)$ for 40,000 iterations after a burn-in period of 40,000 iterations with the LOCPRIOR model (Hubisz et al. 2009) under an admixture ancestral model (Falush et al. 2003). 
The data of mean annual temperature and total annual precipitation in study regions were collected from the State HydroMeteorological Administration of DPR Korea.

\section{Results}

3.1. Genetic diversity and population differentiation of 9 regional populations

Table 1. Geographic distribution and genetic diversity indices of 9 Japanese black pine populations of Korean peninsula

\begin{tabular}{|clllllll|}
\hline ID & region $^{\text {a }}$ & latitude & longitude & $A R$ & $H_{S}$ & $F_{I S}$ \\
\hline 1 & Ongjin & 37.56 & 125.21 & 10.7 & 0.832 & 0.128 \\
\hline 2 & Kangryong & 37.54 & 125.3 & 10.3 & 0.838 & 0.119 \\
\hline 3 & Kosan & 38.51 & 127.25 & 19.5 & 0.806 & 0.164 \\
\hline 4 & Thongchon & 38.57 & 127.53 & 10.7 & 0.843 & 0.210 \\
\hline 5 & Kumya & 39.32 & 127.15 & 8.8 & 0.798 & 0.211 \\
\hline 6 & Hongwon & 40.01 & 127.58 & 6.4 & 0.789 & 0.232 \\
\hline 7 & Sinpho & 40.02 & 128.11 & 8.3 & 0.702 & 0.187 \\
\hline 8 & Riwon & 40.19 & 128.4 & 7.4 & 0.796 & 0.145 \\
\hline 9 & Tanchon & 40.27 & 128.54 & 6.7 & 0.682 & 0.216 \\
\hline
\end{tabular}

a Ongjin and Kangryong are western parts, Kosan and Thongchon are eastern parts, the others are northern parts of Korean peninsula.

Table 1 exhibits geographical distribution of sampled sites, $H_{S} A R, F_{I S}$ of 9 Japanese black pine regional populations in Korean peninsula. Both eastern and western populations exhibited higher genetic diversity and allelic richness comparing with northern populations. On the other hand, northern populations showed higher $F_{I S}$ than that of both eastern and western ones.

Table 2. Hierarchical analysis of molecular variance of SSR markers within sites, among sites within regions, within regions of Korea

\begin{tabular}{|lclllll|}
\hline Population hierarchy & df & $\begin{array}{l}\text { Sum of } \\
\text { squares }\end{array}$ & Variance $^{\mathrm{b}}$ & $\begin{array}{l}\text { Percent } \\
\text { variation }\end{array}$ & $\begin{array}{l}\text { Fixation } \\
\text { indices }\end{array}$ & Significance \\
\hline Among regions & 2 & 24.931 & $0.01391 \mathrm{Va}$ & 0.45 & $\mathrm{~F}_{\mathrm{CT}}=0.005$ & $\mathrm{P}=0.23$ \\
\hline $\begin{array}{l}\text { Among sites within } \\
\text { regions }\end{array}$ & 6 & 66.198 & $0.17883 \mathrm{Vb}$ & 5.81 & $\mathrm{~F}_{\mathrm{SC}}=0.058$ & $\mathrm{P}<0.00001$ \\
\hline Within sites & 407 & 1173.534 & $2.88338 \mathrm{Vc}$ & 93.73 & $\mathrm{~F}_{\mathrm{ST}}=0.062$ & $\mathrm{P}<0.00001$ \\
\hline
\end{tabular}

a region: west $(1,2)$, east(3,4), north(5-9)

${ }^{\mathrm{b}} V_{a}$ is $\sigma=\left(\mathrm{F}_{\mathrm{CT}}\right) \sigma^{2} ; V_{b}$ is $\sigma=\left(\mathrm{F}_{\mathrm{ST}}-\mathrm{F}_{\mathrm{CT}}\right) \sigma^{2} ; V_{c}$ is $\sigma=\left(1-\mathrm{F}_{\mathrm{ST}}\right) \sigma^{2} ; \sigma^{2}=\sigma+\sigma+\sigma$

Table 2 shows hierarchal significance of 9 Japanese black pine populations of Korean peninsula. There was no significant difference among regions but difference among sites within regions and within sites. 
Table 3. Estimates of pairwise genetic differentiation among 9 Japanese black pine regional populations

\begin{tabular}{|c|c|c|c|c|c|c|c|c|c|}
\hline & Ongjin & Kangryong & Kosan & Thongchon & Kumya & Hongwon & Sinpho & Riwon & Tanchon \\
\hline Ongjin & & $0.075^{\star}$ & $0.114^{\star}$ & 0.010 & $0.115^{\star}$ & $0.134^{*}$ & $0.097^{*}$ & 0.116 ** & $0.132 *$ \\
\hline Kangryong & $0.034^{*}$ & & 0.068 & $0.087 * *$ & 0.042 & 0.035 & 0.046 & $0.065^{\star \star}$ & $0.057 * *$ \\
\hline Kosan & $0.132^{*}$ & $0.048^{*}$ & & $0.213^{*}$ & $0.086^{*}$ & 0.053 & $0.264^{*}$ & $0.195^{\star}$ & 0.210 \\
\hline Thongchon & 0.006 & $0.050 * *$ & $0.320 *$ & & $0.073^{\star}$ & $0.049 *$ & 0.048 & $0.148^{*}$ & $0.055^{\star}$ \\
\hline Kumya & $0.063^{* *}$ & 0.025 & $0.064^{\star}$ & $0.057^{*}$ & & 0.049 & 0.043 & $0.049 * *$ & 0.043 \\
\hline Hongwon & $0.057 * * *$ & 0.018 & $0.061^{*}$ & $0.026^{*}$ & 0.016 & & 0.004 & 0.042 & 0.018 \\
\hline Sinpho & $0.210 * *$ & $0.027 *$ & $0.329 *$ & $0.075^{\star}$ & 0.048 & 0.026 & & $0.022^{\star *}$ & 0.013 \\
\hline Riwon & $0.392^{\star * *}$ & $0.036^{*}$ & 0.239 & $0.034^{\star}$ & 0.085 & $0.061^{*}$ & 0.050 & & 0.043 \\
\hline Tanchon & $0.040 *$ & $0.073^{*}$ & $0.39 *$ & $0.038^{*}$ & 0.058 & 0.036 & 0.063 & 0.040 & \\
\hline
\end{tabular}

Pairwise $R_{S T}$ values above the diagonal and pairwise $F_{S T}$ values below the diagonal.

${ }^{\star} P<0.05, * \star P<0.01, * \star \star * P<0.001$.

Table 3 shows genetic differentiation of Japanese black pine individuals in Korean peninsula. Although some distant populations didn't exhibit significant genetic differentiation, generally populations that are apart showed significant genetic differentiation.

\subsection{Association between Japanese black pine range expansion and climate change}

To assess the effects of climate on the expansion of distribution of Japanese black pine, we collected annual average air temperature data of 9 sampled sites in 1980-2019. As shown above, 40 years annual air temperature change exhibited increasing trends in spite of its oscillating pattern. In particular, annual air temperature in the north of Kumya exhibited steeper increase than in other regions. In contrast all study regions exhibited slight changes in precipitation and these changes were not significant as air temperature. Since 2000, all sampled sites have had higher annual air temperature than that of Ongjin in 1980, and owing to the fact that old Japanese black pine stands exist in Ongjin, it indicates that since 2000, all sampled sites would have suitable climate conditions for the distribution of Japanese black pine.

\section{Discussion}

It would be helpful to understand population dynamics, genetic diversity and phylogeographic relationship of regional populations of forest tree species using molecular markers to improve forest conservation and management (Kassa et al., 2017). Kassa et al. (2017) assessed genetic diversity of 4 natural Olea europaea populations using nuclear microsatellite markers and verified solutions for forest management and conservation. Raffl et al. (2018) clarified genetic evidence of human-mediated historical seed transfer from Alps to Carpathian of larch (Larix decidua) forest using nuclear SSR markers. Jansen et al. (2017) assessed influence of artificial gene flow on distribution of Norway spruce from seventeenth century to now combining molecular markers and historical records. These results suggest that combining molecular markers and historical distribution data would be helpful to assess genetic background of forest tree species populations and to establish conservation strategy.

Many studies on phylogenetic relationship of various regional populations of genus Pinus species have been reported. Li Hui-yu et al. (2005) verified genetic variation of 9 Pinus sylvestris populations of Chinese northeastern region using 10 ISSRs and classified them into two origin groups. Lech et al. (2019) assessed genetic structure of 4 remaining Scots pine 
populations distributed in Mt. Tetra using 8 chloroplast microsatellite markers and proposed its status as historical refugia during ice age. Yang et al. (2016) reported nucleotide diversity and phylogeographic relationship of populations of Pinus bungeana, an endangered species distributed in western central areas of China and suggested the west of Qinling Daba as putative refugia.

One of the factors influencing population demography in forest tree species is none other than climate change and researches on historical climate change resulting in distribution change have been reported. Iwaizumi et al. (2018) assessed genetic diversity of cultivated Japanese black pine populations distributed in overall parts of Japan using nuclear SSR markers and suggested potential expansion from southwest refugia to northeast following glaciation. Potential range expansion of red pine populations from glacial refugia to present range in the north east of North America has also been reported (Boys et al. 2005). On the basis of modeling methods, Thuiller (2003) predicted the forest distribution of sessile oak (Quercus petraea) in 2080 under the various climate change and greenhouse emission models and reported northward expansion of forest distribution.

Use of environmental data would assist understanding of possible effects of non-biological factors and associated biological factors on geographic limit of lineage and species (Graham et al. 2004; Soberón and Peterson, 2005; Wiens and Graham, 2005). Integrating both genetic and environmental data in the populations unclarified morphologically and genetically would assist determination of their taxonomic lineage and understanding of mechanisms resulting in their geographic distribution (Hickerson et al. 2010; Newman and Rissler, 2011; Rosell et al. 2010; Ruiz- Sanchez and Sosa, 2010). Korean peninsula includes northern limit of the distribution of Pinus thunbergii Parl. in Asia and is likely to experience the change of forest limit. We discuss the change of forest limit in Korean peninsula in the context of climate change and researches from other regions. For recent decades, Korean peninsula exhibited annual air temperature increase (Om et al. 2019) and it would make it possible for Japanese black pine individuals grow in Kumya where they were unable to grow before.

These results provide genetic evidence of stable northward extension of P.thunbergii populations in the DPR Korea. Although Japanese black pine populations in the north of Kumya formed from planted ones originated from eastern part of peninsula, it is unable to reject spatial connection of populations given high hybridity of the Pinus species and long distance migration characteristics. But structure analysis results suggest that northern populations possessed its own genetic differentiation due to its extensive cultivation and gene flow via wind-driven pollen was not strong enough to homogenize genetic differentiation. Low genetic diversity in Japanese black pine populations in northern group would require additional conservation management.

Recent climate change and extensive afforestation may cause stable northward extension of Japanese black pine forests. Expansion of favorable habitat due to climate change and both afforestation and gene flow into newly formed habitat would be important factors resulting in range expansion of the species. Japanese black pine exhibits low cold tolerance compared to Japanese red pine and grows well in warm areas. Substantial air temperature increase in northern region would allow extensive afforestation of Japanese black pine and it would lead to existence of the populations in northern region. But gene flow from central region to peripheral ones may inhibit genetic differentiation in marginal ones (Kirkpatrick and Barton 1997; Bridle and Vines 2007). Given that dispersal limit of wind-driven pollen in genus Pinus is 40 3000km (Campbell et al. 1999, Varis et al. 2009, Williams 2010) and that $100 \mathrm{~km}$ of effective dispersal distance in Scots pine (Robledo-Amuncio 2011), gene flow through pollen dispersal between eastern and northern regions is likely to happen. Genetic differentiation and relative stability of northern Japanese black pine populations formed as disaster preventive forests suggest that influence of afforestation on range expansion would be dominant compared to gene flow.

Although annual air temperature increase would enable the cultivation of Japanese black pine in the north of Kumya, it is unlikely to claim annual air temperature rise directly led to expansion of Japanese black pine to the north of Kumya. In study regions, extensive afforestation through cultivation seems to have more influence than natural migration from south to north. Recently, Japanese black pine is widely cultivated through plantation in northern coastal areas including Kumya and 
Tanchon. It is no strange that northern regional artificial forests exhibits lower genetic diversity than that of eastern and western region natural ones.

Different climatic conditions in different regions would lead to different distribution of forest limit. In Korean peninsula, northern limit of overall distribution of Japanese black pine is lower in latitude than that of Japan (Iwaizumi et al. 2018). In China, Japanese black pine has been reported to exist in Dalian, Shandong coastal areas, Wuhan, Nanjing, Shanghai, Hangzhou, which is lower in latitude than that of Korean peninsula (Mao et al. 2019). These differences of forest limit maybe due to the effects of both continental and marine climate on forest in Korean peninsula, whereas China is affected by continental climate, Japanese by seasonal one. Our results support validity of northward extension of Pinus thunbergii Parl. populations through recent extensive afforestation and suggest upcoming northward extension given recent climate change.

\section{Conclusion}

The increment of substantial air temperature in study regions, genetic stability and differentiation of northern populations formed recently through afforestation suggests dominant affection of afforestation on expansion of forest distribution. Our results suggest that substantial air temperature increment allowed stable anthropogenic northward extension of Japanese black pine forests.

\section{Declarations}

\section{Contributions of the co-authors}

UH and SS designed the study and conducted the experiments, and HP, KK, TH and IJ analysed the data; UH and SS collected data and wrote the first draft; and all authors contributed substantially to revisions.

\section{Acknowledgements}

We thank all volunteers who collected samples and assisted laboratory work and data analysis.

\section{Declaration on conflicts of interest}

The authors declare that they have no conflict of interest.

\section{References}

1. Boys J, Cherry M, Dayanandan S (2005) Microsatellite analysis reveals genetically distinct populations of red pine (Pinus resinosa, Pinaceae). Am J Bot 92(5):833-841

2. Bridle JR, Vines TH (2007) Limits to evolution at range margins: when and why does adaptation fail? Trends Ecol Evol 22:140-147

3. Campbell ID, McDonald K, Flannigan MD, Kringayark J (1999) Longdistance transport of pollen into the Arctic. Nature 399:29-30

4. Cheaib A, Badeau V, Boe J, Chuine I, Delire C, Dufrene E, Francois C, Gritti ES, Legay M, Page C, Thuiller W, Viovy LP (2012) Climate change impacts on tree ranges: model intercomparison facilitates understanding and quantification of uncertainty. Ecol Lett 15:533-544

5. Doyle JJ, Doyle JL (1987) A rapid DNA isolation procedure for small quantities of fresh leaf tissue. Phytochem Bull 19:11-15

6. Etterson JR, Shaw RG (2010) Constraint to adaptive evolution in response to global warming. Science 294:151-154 
7. Excoffier L, Lischer HEL (2010) Arlequin suite ver 3.5: a new series of programs to perform population genetics analyses under Linux and Windows. Mol Ecol Resour 10:564-567

8. Falush D, Stephens M, Pritchard JK (2003) Inference of population structure using multilocus genotype data: linked loci and correlated allele frequencies. Genetics 164:1567-1587

9. Fettig CJ, Mortenson LA, Bulaon BM, Foulk PB (2018) Tree mortality following drought in the central and southern Sierra Nevada, California, U. S. For. Ecol. Manage 432:164-178

10. Freire JA, Rodrigues GC, Tome M (2019) Climate Change Impacts on Pinus pinea L. Silvicultural System for Cone Production and Ways to Counter Those Impacts: A Review Complemented with Data from Permanent Plots. For, 10: 169

11. Goudet J (2003) FSTAT (ver. 2.9.4), a program to estimate and test population genetics parameters. https://www2.unil.ch/popgen/softwares/fstat.htm. Accessed 21 November 2003

12. Graham CH, Ron S, Santos JC, Schneider CJ, Moritz C (2004) Integrating phylogenetics and environmental niche models to explore speciation mechanisms in dendrobatid frogs. Evolution 58:1781-1793

13. Hickerson MJ, Carstens BC, Cavender-Bares J, Crandall KA, Graham CH, Johnson JB, Rissler L, Victoriano PF, Yoder AD (2010) Phylogeography's past, present, and future: 10 years after Avise, 2000. Mol Phylogenet Evol 54:291-301

14. Ho UH, Song SR (2020) Did genetic lineage divergence or spatial environmental variance lead to global subspecies differentiation of northern goshawk (Accipiter gentilis). Anim Biol 70:289-308

15. Hubisz M, Falush D, Stephens M, Pritchard J (2009) Inferring weak population structure with the assistance of sample group information. Mol Ecol Resour 9:1322-1332

16. Iwaizumi MG, Miyata S, Hirao T, Tamura M, Watanabe A (2018) Historical seed use and transfer affects geographic specificity in genetic diversity and structure of old planted Pinus thunbergii populations. For Ecol Manage 408:211-219

17. Iwaizumi MG, Takahashi M, Isoda K, Austerlitz F (2013) Consecutive five-year analysis of paternal and maternal gene flow and contributions of the gametic heterogeneities to overall genetic composition of Pinus densiflora dispersed seeds. Am J Bot 100:1896-1904

18. Jansen S, Konrad H, Geburek T (2017) The extent of historic translocation of Norway spruce forest reproductive material in Europe. Ann For Sci 75(56). DOI: https://doi.org/10.1007/s13595-017-0644-z

19. Kang YS, Ryu JG, Kim SC, Ri HJ (2002) Research of age and ancient natural environment of mankind fossil discovered from Kunbong. Thesis Collections, Kim II Sung University Natural Science, 48(12): 91-97

20. Kassa A, Konrad H, Geburek T (2017) Landscape genetic structure of Olea europaea subsp. cuspidata in Ethiopian highland forest fragments. Conserv Genet 18(6):1463-1474

21. Keenan T, Serra JM, Lloret F, Nilyerola M, Sabate S (2010) Predicting the future of forests in the Mediterranean under climate change, with niche- and process-based models: $\mathrm{CO}_{2}$ matters! Glob. Change Biol 10:1365-2486

22. Kirkpatrick M, Barton NH (1997) Evolution of a species range. Am Nat 150:1-23

23. Konta F (2001) The present conditions and functions of the coastal forests in Japan. J Jpn Soc Coast For 1:1-4

24. Lech U, Aleksandra WP, Konrad C, Paulina L, Ewa P, Algis A (2019) Genetic resources of relict populations of Pinus sylvestris (L.) in Western Carpathians assessed by chloroplast microsatellites. Biologia 74:1077-1086

25. Lenoir J, Gegout JC, Marquet PA, De Ruffray P, Brise H (2008) A significant upward shift in plant species optimum elevation during 20th century. Science 320:1768-1771

26. Li HY, Jiang J, Liu GF, Ma XJ, Dong JX, Lin SJ (2005) Genetic variation and division of Pinus sy/vestris provenances by ISSR markers. J Forestry Res 16(3):216-218

27. Mao P, Guo L, Gao Y, Qi L, Cao B (2019) Effects of Seed Size and Sand Burial on Germination and Early Growth of Seedlings for Coastal Pinus thunbergii Parl. In the Northern Sandong Peninsula. China For 10:281

28. Misi D, Puchalka R, Pearson C, Robertson I, Koprowski M (2019) Differences in the Climate-Growth Relationship of Scots Pine: A case Study from Poland and Hungary. For 10:243

Page 8/12 
29. Mousadik El, Petit A (1996) High level of genetic differentiation for allelic richness among populations of the argan tree [Argania spinosa (L.) Skeels] endemic to Morocco. Theor Appl Genet 92:832-839

30. Murai H, Ishikawa M, Endo J, Tadaki Y (1992) The Coastal Forest in Japan. Soft Science Inc, Tokyo

31. Nei M (1987) Molecular Evolutionary Genetics. Columbia University Press, New York

32. Newman CE, Rissler LJ (2011) Phylogenetic analyses of the southern leopard frog: the impact of the geography and climate on the distribution of genetic lineages vs. subspecies. Mol Ecol 20:5295-5312

33. Ogawa M (1979) Microbial flora in Pinus thunbergii forest of coastal sand dune. Bull Forestry For Prod Res Inst 305:107-124

34. Om GC, Ren G, Jong SI, Li S, O KC, Ryang CH, Zhang P (2019) Long-term change in surface air temperature over DPR Korea, 1918-2015. Theor Appl Climatol 138:363-372

35. Pritchard JK, Stephens M, Donnelly P (2000) Inference of population structure using multilocus genotype data. Genetics 155:945-959

36. Pritchard JK, Wen X, Falush D (2009) STRUCTURE version 2.3.1 [computer program]. Available from:http://pritch.bsd.uchicago.edu/structure.html

37. Raffl H, Konrad H, Curtu LA, Geburek T (2018) Genetic evidence of human mediated, historical seed transfer from the Tyrolean Alps to the Romanian Carpathians in Larix decidua (Mill) forests, Annals of Forest Science. 75. https://doi.org/10.1007/s13595-018-0776-9. 98

38. Robledo-Arnuncio JJ (2011) Wind pollination over mesoscale distances: an investigation with Scots pine. New Phytol 190:222-233

39. Rogers SO, Bendich AJ (1988) Extraction of DNA from plant tissues. Plant Mol Biol (Manual) A6:1-10

40. Rosell JA, Olson ME, Weeks A, De-Nova JA, Medina-Lemos R, Pérez-Camacho J, Feria TP, Gómez-Bermejo R, Montero JC, Eguiarte LE (2010) Diversification in species complexes: tests of species origin and delimitation in the Bursera simaruba clade of tropical trees (Burseraceae). Mol Phylogenet Evol 57:798-811

41. Ruiz-Sanchez E, Sosa V (2010) Delimiting species boundaries within the Neotropical bamboo Otatea (Poaceae: Bambusoideae) using molecular, morphological and ecological data. Mol Phylogenet Evol 54:912344-912356

42. Soberón J, Peterson AT (2005) Interpretation of models of fundamental ecological niches and species' distributional areas. Biodiversity Informatics 2:1-10

43. Thuiller W (2003) BIOMOD - optimizing predictions of species distributions and projecting potential future shifts under global change. Glob Change Biol 9:1353-1362

44. Varis S, Pakkanen A, Galofre' A, Pulkkinen P (2009) The extent of southnorth pollen transfer in Finnish Scots pine. Silva Fenn 43:717-726

45. Wiens JJ, Graham CH (2005) Niche conservatism: integrating evolution, ecology, and conservation biology. Annu Rev Ecol Evol S 36:519-539

46. Williams CG (2010) Long-distance pine pollen still germinates after meso-scale dispersal. Am J Bot 97:846-855

47. Yang YX, Wang ML, Liu ZL, Zhu J, Yan MY (2016) Nucleotide polymorphism and phylogeographic history of an endangered conifer species Pinus bungeana. Biochem Syst Ecol 64:89-96

48. Yeh FC, Boyle TJB (1997) Population genetic analysis of co-dominant and dominant markers and quantitative traits. Belg J Bot 29:157

49. Zhu J, Matsuzaki T, Sakioka K (2000) Windspeeds within a single crown of Japanese black pine (Pinus thunbergii Parl.). For Ecol Manage 135:19-31

\section{Figures}




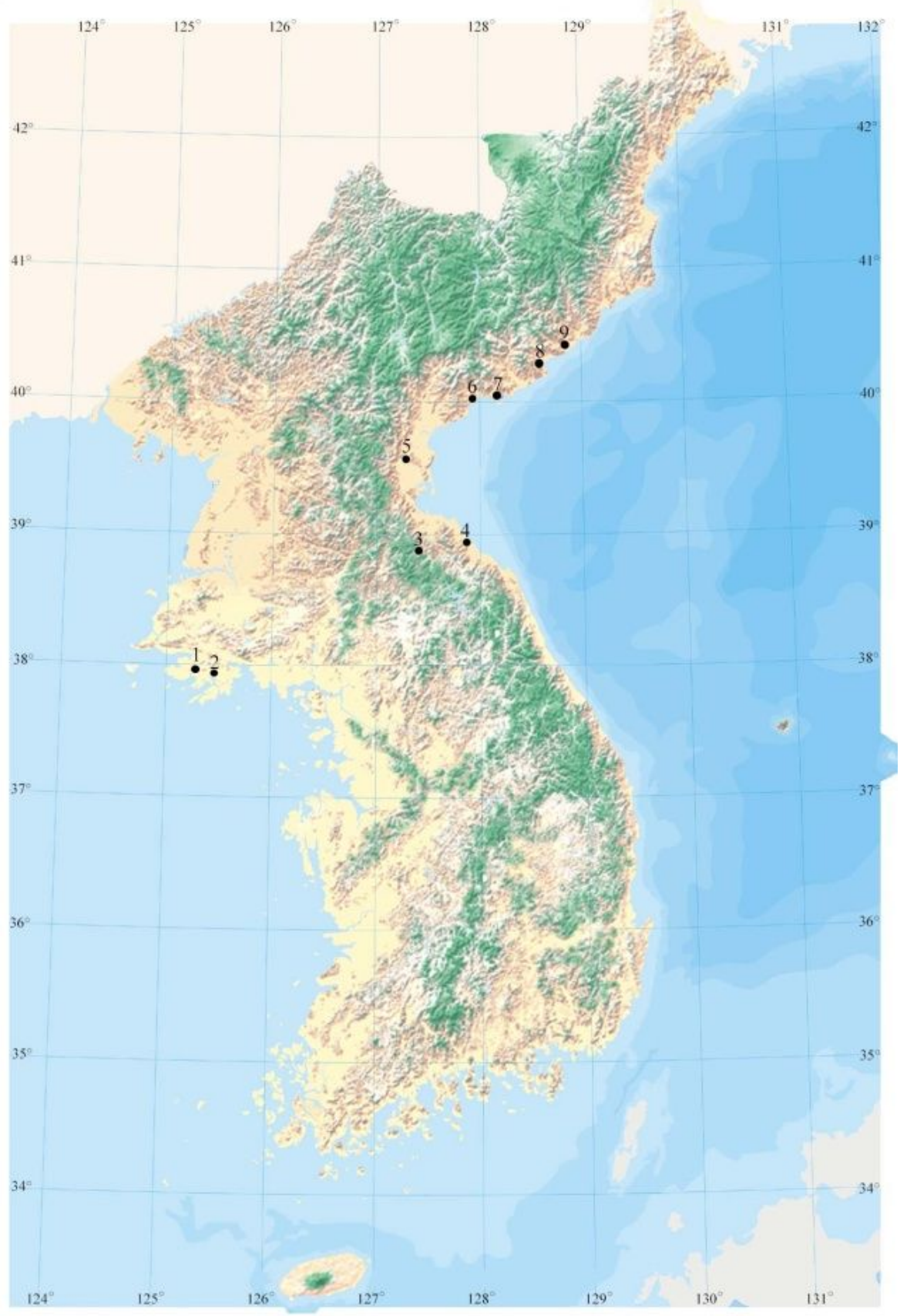

\section{Figure 1}

Sample sites of Japanese black pine in Korean peninsula The location information is as indicated in Table 1. 

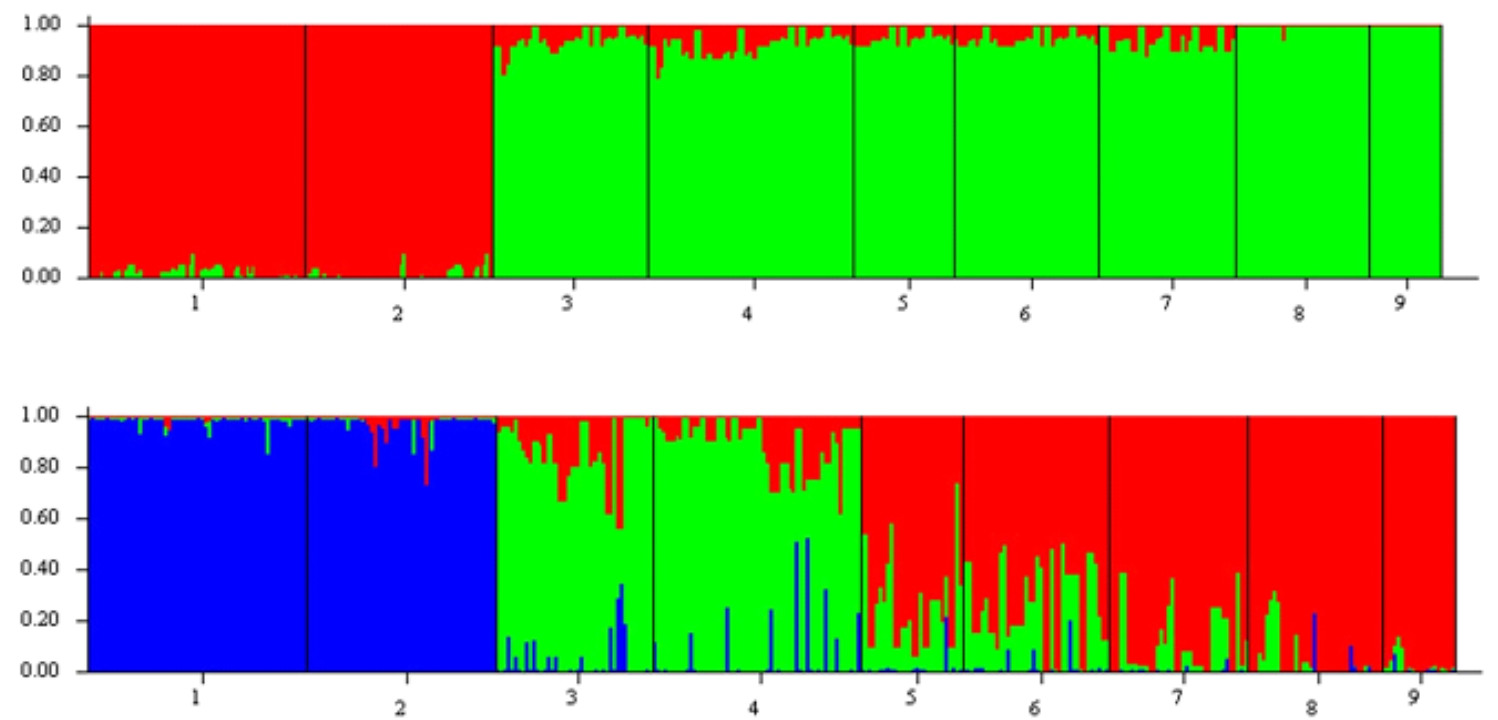

Figure 2

STRUCTURE analysis with the LOCPRIOR model in the 9 Japanese black pine populations 

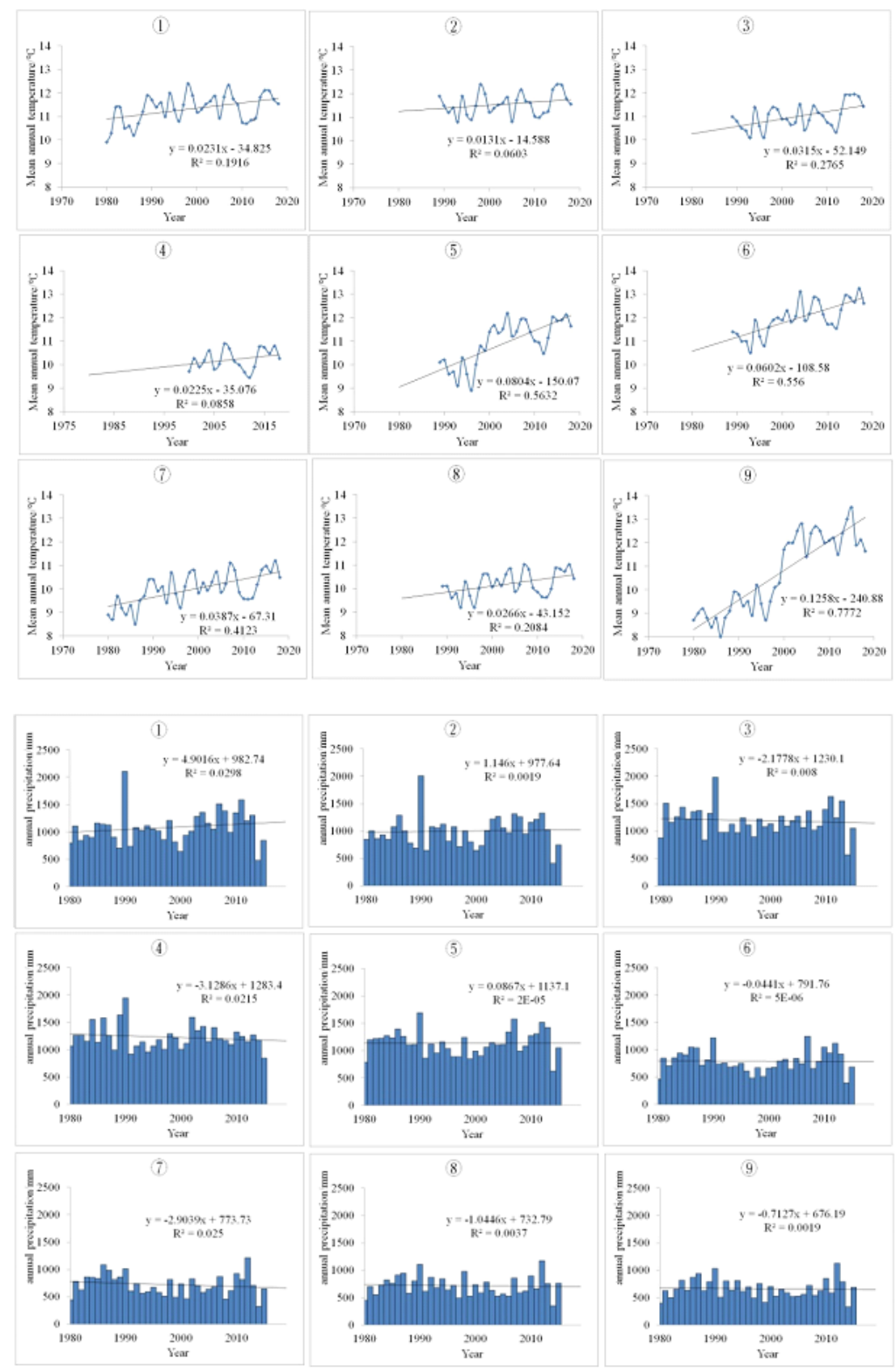

\section{Figure 3}

Annual average air temperature change in 9 sites of Korean peninsula in 1980-2019, The location information is as indicated in Table 1. 